\title{
Derivation of Residual Radioactive Material Guidelines for Uranium in Soil at the Former Associate Aircraft Tool and Manufacturing Company Site, Fairfield, Ohio
}

by E.R. Faillace, M. Nimmagadda, and C. Yu

Environmental Assessment Division,

Argonne National Laboratory, 9700 South Cass Avenue, Argonne, Illinois 60439

January 1995

Work sponsored by United States Department of Energy,

Office of Environmental Restoration, Washington, D.C. 


\section{DISCLAIMER}

This report was prepared as an account of work sponsored by an agency of the United States Government. Neither the United States Government nor any agency thereof, nor any of their employees, make any warranty, express or implied, or assumes any legal liability or responsibility for the accuracy, completeness, or usefulness of any information, apparatus, product, or process disclosed, or represents that its use would not infringe privately owned rights. Reference herein to any specific commercial product, process, or service by trade name, trademark, manufacturer, or otherwise does not necessarily constitute or imply its endorsement, recommendation, or favoring by the United States Government or any agency thereof. The views and opinions of authors expressed herein do not necessarily state or reflect those of the United States Government or any agency thereof. 


\section{DISCLAIMER}

Portions of this document may be illegible in electronic image products. Images are produced from the best available original document. 


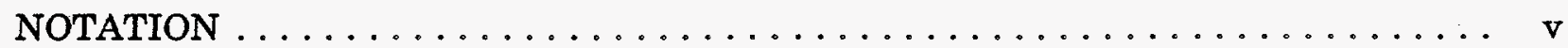

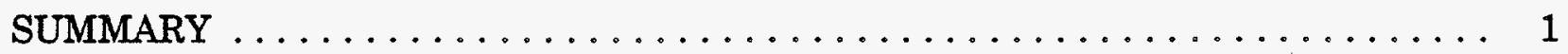

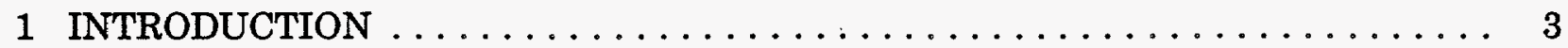

1.1 Site Description and Setting $\ldots \ldots \ldots \ldots \ldots \ldots \ldots \ldots \ldots \ldots \ldots \ldots \ldots \ldots \ldots \ldots$

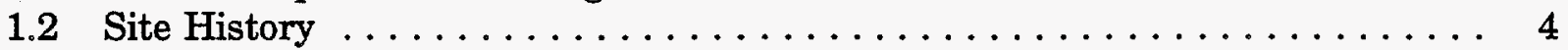

1.3 Derivation of Cleanup Guidelines $\ldots \ldots \ldots \ldots \ldots \ldots \ldots \ldots \ldots$

2 SCENARIO DEFINITIONS $\ldots \ldots \ldots \ldots \ldots \ldots \ldots \ldots \ldots \ldots \ldots \ldots \ldots \ldots \ldots \ldots$

3 DOSE/SOURCE CONCENTRATION RATIOS $\ldots \ldots \ldots \ldots \ldots \ldots \ldots \ldots \ldots$

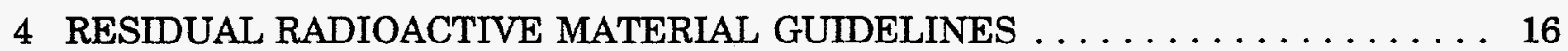

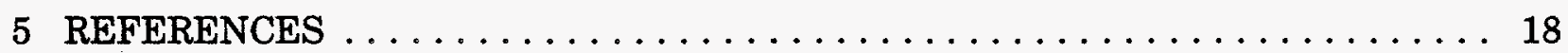

APPENDIX: Scenarios and Parameters Used for the Analysis

of the Former Associate Aircraft Site $\ldots \ldots \ldots \ldots \ldots \ldots \ldots$

FIGURES

1 Map Showing Fairfield, Ohio, Location of the Former Associate Aircraft Site . . . . . . . . . . . . . . . . 4

2 Layout of the Former Associate Aircraft Building $\ldots \ldots \ldots \ldots \ldots \ldots$

3 Diagram Showing the Area Surveyed in July 1992 West of the Building at the Former Associate Aircraft Site $\ldots \ldots \ldots \ldots \ldots \ldots \ldots$

\section{TABLES}

1 Summary of Exposure Pathways for Scenarios A, $\mathrm{B}$, and $\mathrm{C}$ at the Former Associate Aircraft Site

2 Maximum Dose/Source Concentration Ratios for Scenario A at the Former Associate Aircraft Site

3 Maximum Dose/Source Concentration Ratios for Scenario B at the Former Associate Aircraft Site $\ldots \ldots \ldots \ldots \ldots \ldots \ldots \ldots \ldots$

4 Maximum Dose/Source Concentration Ratios for Scenario C at the Former Associate Aircraft Site 


\section{TABLES (Cont.)}

5 Total Dose/Source Concentration Ratios for Uranium at the Former Associate Aircraft Site

6 Residual Radioactive Material Guidelines

for the Former Associate Aircraft Site

$7 \quad$ Ranges for Hot-Spot Multiplication Factors $\ldots \ldots \ldots \ldots \ldots \ldots \ldots \ldots$

A.1 Parameters Used in the RESRAD Computer Code

for the Analysis of the Former Associate Aircraft Site 
The following is a list of the acronyms, initialisms, abbreviations, and units of measure used in this document. Some notations used in tables or equations only are defined only in the respective tables or equations.

\section{ACRONYMS, INITIALISMS, AND ABBREVIATIONS}
AEC
U.S. Atomic Energy Commission
ALARA as low as reasonably achievable
DOE U.S. Department of Energy
FUSRAP Formerly Utilized Sites Remedial Action Program
NLO National Lead of Ohio
ORNL Oak Ridge National Laboratory
RESRAD residual radioactive material guideline computer code

\section{UNITS OF MEASURE}

$\begin{array}{ll}\mathbf{c m} & \text { centimeter(s) } \\ \mathrm{cm}^{3} & \text { cubic centimeter(s) } \\ \mathrm{d} & \text { day(s) } \\ \mathrm{ft} & \text { foot (feet) } \\ \mathrm{g} & \text { gram(s) } \\ \mathrm{h} & \operatorname{hour}(\mathrm{s}) \\ \mathrm{kg} & \operatorname{kilogram}(\mathrm{s}) \\ \mathrm{L} & \operatorname{liter}(\mathrm{s})\end{array}$

$\begin{array}{ll}\mathrm{m} & \text { meter(s) } \\ \mathrm{m}^{2} & \text { square meter(s) } \\ \mathrm{m}^{3} & \text { cubic meter(s) } \\ \mathrm{mg} & \text { milligram(s) } \\ \mathrm{mrem} & \text { millirem(s) } \\ \mathrm{pCi} & \text { picocurie(s) } \\ \mathrm{s} & \text { second(s) } \\ \mathrm{yr} & \text { year(s) }\end{array}$




\title{
DERIVATION OF RESIDUAL RADIOACTIVE MATERIAL GUIDELINES FOR URANIUM IN SOIL AT THE FORMER ASSOCIATE AIRCRAFT TOOL AND MANUFACTURING COMPANY SITE, FAIRFIELD, OHIO
}

\author{
by
}

\author{
E.R. Faillace, M. Nimmagadda, and C. Yu
}

\section{SUMMARY}

Residual radioactive material guidelines for uranium in soil were derived for the former Associate Aircraft Tool and Manufacturing Company site ${ }^{1}$ in Fairfield, Ohio. This site has been identified for remedial action under the U.S. Department of Energy's (DOE's) Formerly Utilized Sites Remedial Action Program (FUSRAP). Single-nuclide and totaluranium guidelines were derived on the basis of the requirement that, after remedial action, the 50-year committed effective dose equivalent to a hypothetical individual living or working in the immediate vicinity of the site should not exceed (1) $30 \mathrm{mrem} / \mathrm{yr}$ for the current-use and likely future-use scenarios or (2) $100 \mathrm{mrem} / \mathrm{yr}$ for less likely future-use scenarios (Yu et al. 1993a). The DOE residual radioactive material (RESRAD) computer code, which implements the methodology described in the DOE manual for establishing residual radioactive material guidelines, was used in this evaluation.

Three scenarios are considered in which it is assumed that the site will be used without radiological restrictions for a period of 1,000 years following remedial action. The three scenarios vary with regard to the type of site use, time spent at the site by the exposed individual, and sources of food and water consumed. The evaluation indicates that the dose constraint of $30 \mathrm{mrem} / \mathrm{yr}$ would not be exceeded for uranium (including uranium-234, uranium-235, and uranium-238) within 1,000 years provided that the soil concentration of total combined uranium (uranium-234, uranium-235, and uranium-238) at the former Associate Aircraft site did not exceed $970 \mathrm{pCi} / \mathrm{g}$ for Scenario A (industrial worker: current-use scenario) or $280 \mathrm{pCi} / \mathrm{g}$ for Scenario B (resident: municipal water supply, a likely future-use scenario). The dose limit of $100 \mathrm{mrem} / \mathrm{yr}$ would not be exceeded at the site if the total uranium concentration of the soil did not exceed $790 \mathrm{pCi} / \mathrm{g}$ for Scenario $\mathrm{C}$ (subsistence farmer: on-site well water, a plausible but unlikely future-use scenario).

The uranium guidelines derived in this analysis apply to the total activity concentration of uranium isotopes (i.e., uranium-238, uranium-234, and uranium-235 present in their natural activity concentration ratio of 1:1:0.046). Consequently, if uranium-238 were measured as the indicator radionuclide, the respective soil concentration limits for Scenarios A, B, and C would be 470,140 , and $390 \mathrm{pCi} / \mathrm{g}$. These guidelines were calculated

1 Referred to as the former Associate Aircraft site in the remainder of the document. 
on the basis of a dose constraint of $30 \mathrm{mrem} / \mathrm{yr}$ for Scenarios A and B and a dose limit of $100 \mathrm{mrem} / \mathrm{yr}$ for Scenario C ( $\mathrm{Yu}$ et al. 1993a). In setting the actual uranium guidelines for the former Associate Aircraft site, DOE will apply the as-low-as-reasonably-achievable (ALARA) policy to the decision-making process, along with other factors, such as whether a particular scenario is reasonable and appropriate. 


\section{INTRODUCTION}

The former Associate Aircraft Tool and Manufacturing Company site ${ }^{2}$ is located in Fairfield, Ohio (Figure 1). The site has been designated by the U.S. Department of Energy (DOE) as a candidate for remedial action under its Formerly Utilized Sites Remedial Action Program (FUSRAP). This designation was made after preliminary inspections by Oak Ridge National Laboratory (ORNL) in July and September 1992 indicated the presence of uranium contamination both inside and outside the building on the site. FUSRAP was established in 1974 by the U.S. Atomic Energy Commission (AEC), a predecessor of DOE. The mandate of the program is to identify, evaluate, and, if necessary, decontaminate sites previously used by the AEC or its predecessor, the Manhattan Engineer District.

Remedial action activities at the former Associate Aircraft site will follow the guidelines established in DOE Order 5400.5 (DOE 1990). The RESRAD computer code (Yu et al. 1993a) is used to derive residual radionuclide guidelines on a site-specific basis. This report presents the uranium guidelines derived for the former Associate Aircraft site on the basis of a dose constraint of $30 \mathrm{mrem} / \mathrm{yr}$ for the current-use and likely future-use scenarios and a dose limit of $100 \mathrm{mrem} / \mathrm{yr}$ for less likely but plausible future-use scenarios (Yu et al. 1993a). The dose constraint of $30 \mathrm{mrem} / \mathrm{yr}$ is not currently required under DOE Order 5400.5 but is included in the proposed 10 CFR Part 834 rulemaking to account for additional dose contributions from other potential sources of radiation exposure.

\subsection{SITE DESCRIPTION AND SETTING}

The building on the former Associate Aircraft site previously housed an operation to machine uranium slugs (Figure 2). The site encompasses approximately $10,000 \mathrm{~m}^{2}$, of which $3,700 \mathrm{~m}^{2}$ is occupied by the building. At the time of the ORNL surveys, the current owner operated a multipurpose shop in the facility. The building faces vacant lots to the south and east and Ohio State Route 4 (Dixie Highway) to the west. Commercial properties are located north of the building.

The town of Fairfield is located in Butler County, Ohio, about 10 miles northwest of Cincinnati (Figure 1). The annual average precipitation rate in nearby Hamilton, Ohio (to the northwest), is $0.99 \mathrm{~m} / \mathrm{yr}$ (Spieker 1965). The soil in the area of the site is predominantly sand and gravel (Spieker 1965). The site currently obtains water from municipal sources, and no wells have been dug on the property. The water table in the area ranges from as close as $2 \mathrm{~m}$ to more than $10 \mathrm{~m}$ below the soil surface (Sheets 1994; Spieker 1965). The distribution coefficient for uranium in a surface soil sample collected near the main entrance to the building was $100 \mathrm{~cm}^{3} / \mathrm{g}$ (Orlandini 1994).

2 Hereafter referred to as the former Associate Aircraft site. 


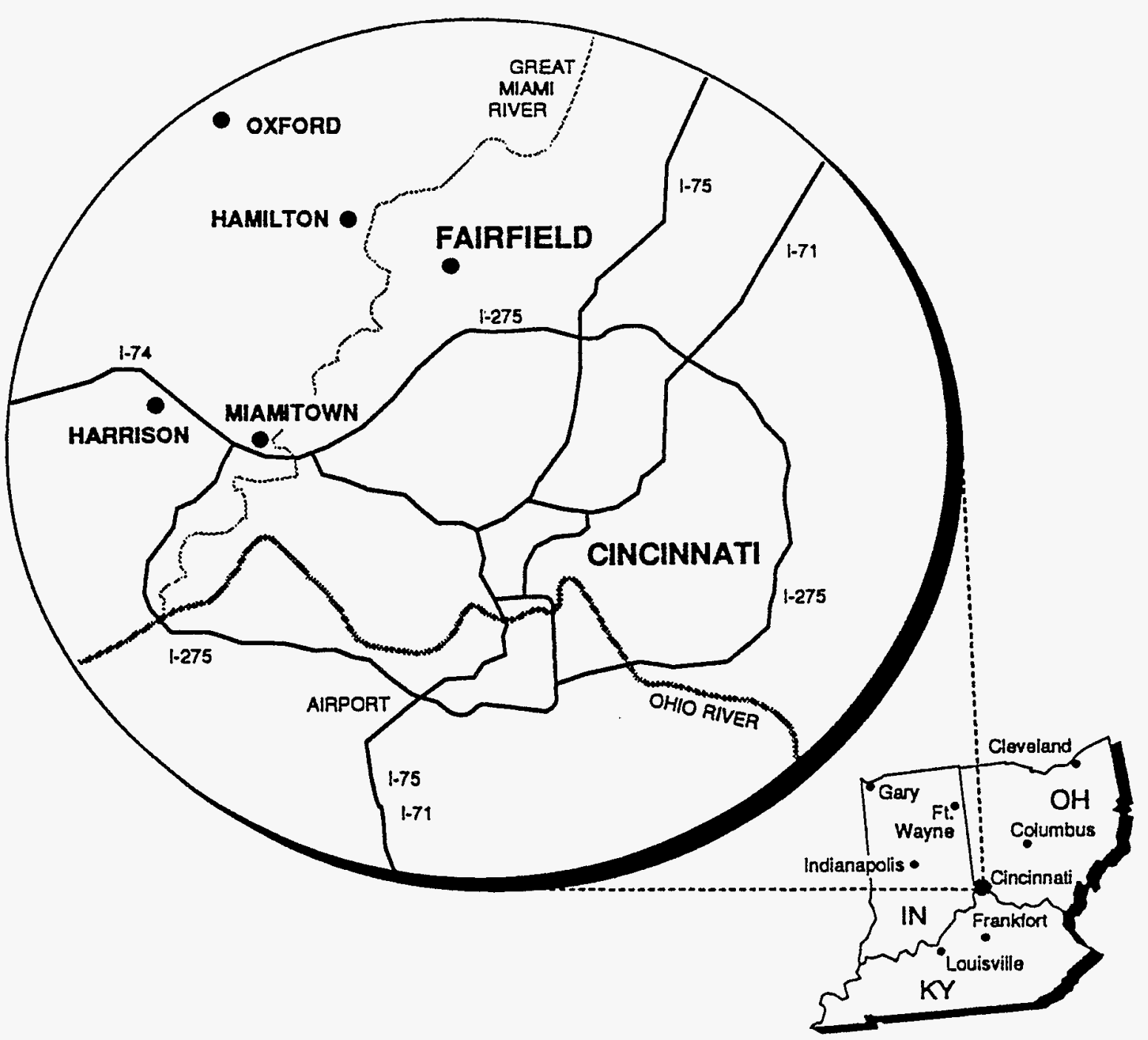

FIGURE 1 Map Showing Fairfield, Ohio, Location of the Former Associate Aircraft Site (Source: Murray et al. 1993)

\subsection{SITE HISTORY}

The Associate Aircraft Tool and Manufacturing Company was a subcontractor to National Lead of Ohio (NLO) from February to September 1956. Hollow uranium slugs were produced at the former Associate Aircraft site for NLO, which was a primary contractor for the AEC. Early operations conducted at the Fairfield site included hollow drilling, reaming, and turning slugs to a final outside diameter. Contractual records indicate that approximately 95,000 slugs were machined during the eight-month period of operation. During the last three months of the contract, Associate Aircraft production was maintained at a minimum operating level of 10,000 to 15,000 slugs per month (Murray et al. 1993). 


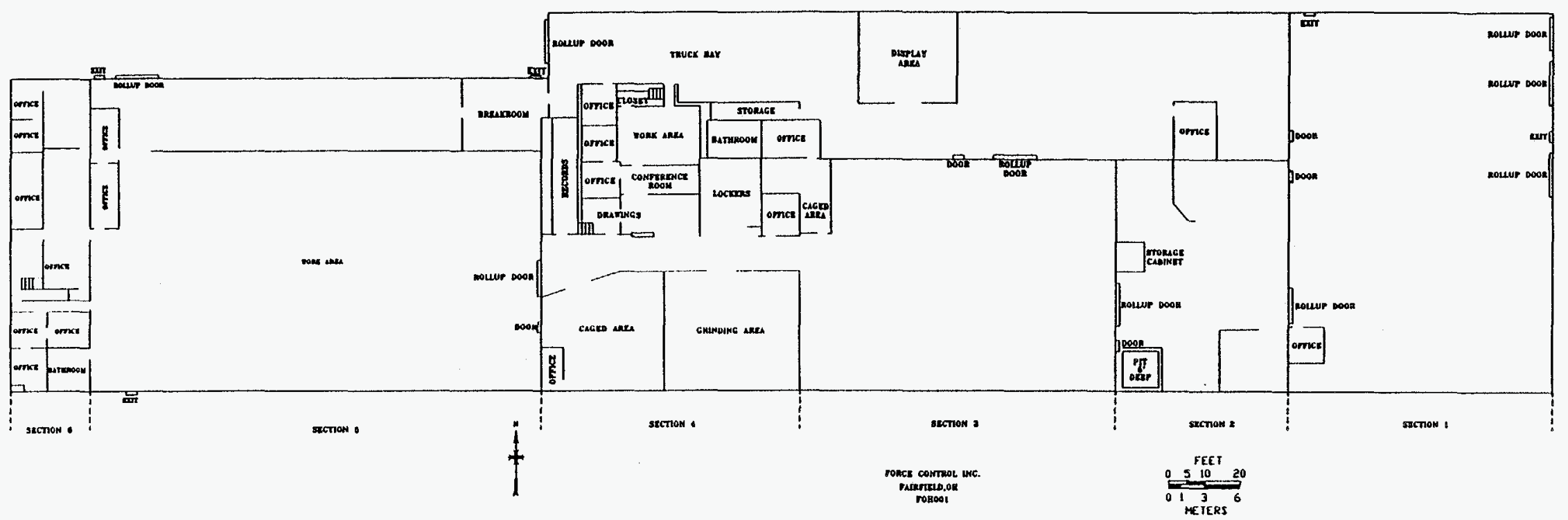

FIGURE 2 Layout of the Former Associate Aircraft Building (Source: Murray et al. 1993) 
The present occupant of the site is Force Control Industries. An employee of that firm who had visited the site in the 1950 s reports that no extensive remodeling of the sole building on the property had been performed before 1992 (Murray et al. 1993). However, the west entrance to the building (Figure 3 ) was remodeled soon after a radiological survey was performed in 1992. Debris from that construction project was placed behind the east end of the building.

The uranium-machining activities performed at the site in the 1950 s contaminated equipment, the building, and land with low levels of radioactive materials. At contract termination, sites used by the contractor were decontaminated in accordance with the standards and survey methods in use at that time. However, since then, more stringent radiological criteria and guidelines have been implemented for the release of such sites for unrestricted use.

In the absence of substantial information regarding the current condition of the former Associate Aircraft site, DOE requested that ORNL personnel conduct a radiological survey of the facility under FUSRAP. The ground surface directly in front (west) of the building was thoroughly surveyed in July, before the front entrance was remodeled. A complete radiological characterization of the building and of a 25 -ft-wide perimeter of ground surface around the other three sides of the building was performed in September 1992. The results indicated that residual uranium contamination from past AEC-related activities exceeds current DOE guidelines in the building and in isolated spots on the site outside the building (Murray et al. 1993).

\subsection{DERIVATION OF CLEANUP GUIDELINES}

Although most DOE cleanup guidelines applicable to remedial actions at FUSRAP sites are generic (DOE 1990), guidelines for uranium are derived on a site-specific basis. The purpose of this analysis was to derive the residual radioactive material guidelines for uranium (i.e., uranium-234, uranium-235, uranium-238, and total uranium) in soil applicable to remedial action at the former Associate Aircraft site. The derived guidelines represent the residual concentration of uranium in a homogeneously contaminated area that must not be exceeded if the site is to be released for use without radiological restrictions. The guideline for total uranium is derived by assuming that uranium-238, uranium-234, and uranium-235 are present in their natural activity concentration ratio of 1:1:0.046.

Site-specific uranium guidelines for the former Associate Aircraft site were derived on the basis of a dose constraint of $30 \mathrm{mrem} / \mathrm{yr}$ for the current-use and likely future-use scenarios and a dose limit of $100 \mathrm{mrem} / \mathrm{yr}$ for less likely but plausible future-use scenarios (Yu et al. 1993a). It was assumed that uranium is the only radionuclide present at an abovebackground concentration. The RESRAD computer code, version 5.41 , was used to derive these guidelines. The RESRAD code is used to implement the methodology described in the DOE manual for establishing residual radioactive material guidelines ( $\mathrm{Yu}$ et al. 1993a). 


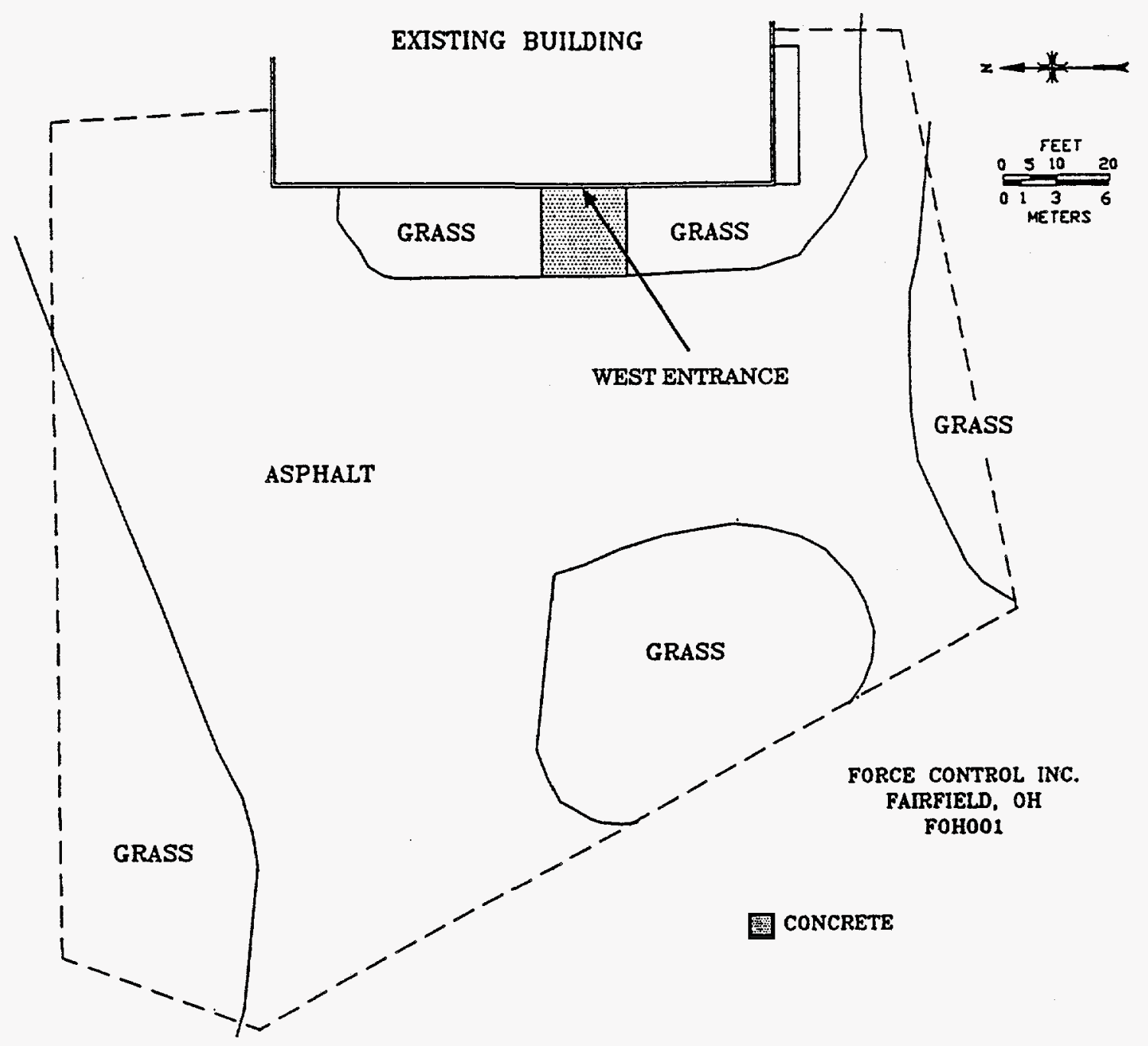

FIGURE 3 Diagram Showing the Area Surveyed (inside dashed line) in July 1992 West of the Building at the Former Associate Aircraft Site (Source: Adapted from Murray et al. 1993) 


\section{SCENARIO DEFINITIONS}

Three potential exposure scenarios (Scenarios A, B, and C) were considered for this assessment of residual radioactivity guidelines for soil. The assumption was made that at some time within 1,000 years, the site will be released for use without radiological restrictions following remedial action (decontamination). Potential radiation doses resulting from nine exposure pathways were considered: (1) direct exposure to external radiation from the decontaminated soil material, (2) internal radiation from inhalation of contaminated dust, (3) internal radiation from inhalation of emanating radon-222, (4) internal radiation from incidental ingestion of soil, (5) internal radiation from ingestion of plant foods grown in the decontaminated area and irrigated with water drawn from a well located at the downgradient edge of the decontaminated area, (6) internal radiation from ingestion of meat from livestock fed with fodder grown in the decontaminated area and irrigated with water drawn from an on-site well, (7) internal radiation from ingestion of milk from livestock fed with fodder grown in the decontaminated area and irrigated with water drawn from an on-site well, (8) internal radiation from the ingestion of fish from a pond downgradient from the decontaminated area, and (9) internal radiation from drinking of water drawn from the on-site well. All exposure pathways considered for the three scenarios are summarized in Table 1.

TABLE 1 Summary of Exposure Pathways for Scenarios A, $B$, and $C$ at the Former Associate Aircraft Site

\begin{tabular}{lccc}
\hline \multicolumn{1}{c}{ Pathway } & Scenario $\mathrm{A}^{\mathrm{a}}$ & Scenario $\mathrm{B}^{\mathrm{b}}$ & Scenario C $^{\mathrm{c}}$ \\
\hline External exposure & Yes & Yes & Yes \\
Inhalation & Yes & Yes & Yes \\
Radon & Yes & Yes & Yes \\
Ingestion of plant foods & No & Yes & Yes \\
Ingestion of meat & No & No & Yes \\
Ingestion of milk & No & No & Yes \\
Ingestion of fish & No & No & Yes \\
Ingestion of soil & Yes & Yes & Yes \\
Ingestion of water & No & No & Yes \\
\hline
\end{tabular}

a Industrial worker: no consumption of water or foods obtained on the site.

b Resident: water used for drinking, household purposes, and irrigation is assumed to be from uncontaminated municipal sources.

c Subsistence farmer: water used for drinking, household purposes, livestock watering, and irrigation is assumed to be from an on-site well. 
Scenario A (the current-use scenario) assumes continued industrial use of the site. Under this scenario, a hypothetical individual is assumed to spend 9 hours per day at the site ( 8 hours working indoors and 1 hour outdoors for lunch), 5 days per week, 50 weeks per year. It is also assumed that the worker does not ingest water, plant foods, or fish obtained from the decontaminated area or meat or milk from livestock raised in the decontaminated area. The dose to the worker is assumed to be only from the decontaminated soil.

Scenario B (a likely future-use scenario) assumes residential use of the site. It is assumed that at some time in the future, the industrial activities at the site will be discontinued, the existing building will be removed, and the whole site will be transformed into a residential area. A hypothetical resident of the site is assumed to ingest plant foods grown in a garden on the site. All water used by the resident for drinking, household purposes, and irrigation is from municipal sources that are not radioactively contaminated. For this scenario, it is assumed that no livestock are raised on the site for the production of meat and milk and no pond is present to provide fish or other aquatic food.

Scenario C (a plausible but unlikely future-use scenario) is similar to Scenario B, in which a resident is assumed to ingest plant foods grown in the garden. However, under Scenario $\mathrm{C}$, the resident is a subsistence farmer who is also assumed to ingest meat and milk from livestock fed with forage grown on-site and to consume fish and other aquatic organisms caught from an on-site pond. For this scenario, the groundwater drawn from a well located on-site is the only water source for drinking, household use, livestock watering, and irrigation. Currently no agricultural activity occurs at the site, and production of livestock or construction of a fishing pond in the decontaminated area is considered extremely unlikely. Agricultural use of the property would require removal of the current building and the paved areas at the site. For the purposes of this analysis, it is assumed that any residual soil contamination would not be removed during this process.

The RESRAD computer code (Yu et al. 1993a) was used to calculate the potential radiation doses for the hypothetical future industrial worker (Scenario $A$ ) and the resident and subsistence farmer (Scenarios $B$ and $C$ ) on the basis of the following assumptions:

- During one year, the industrial worker (Scenario A) spends 2,000 hours ( $23 \%$ of the time) indoors at the decontaminated site, 250 hours (3\%) outdoors at the site, and 6,510 hours $(74 \%)$ away from the site. The resident and subsistence farmer (Scenarios $\mathrm{B}$ and $\mathrm{C}$ ) during one year spend 4,380 hours $(50 \%)$ indoors, 2,190 hours $(25 \%)$ outdoors in the decontaminated area, and 2,190 hours (25\%) away from the site ( $\mathrm{Yu}$ et al. 1993a).

- The walls, floor, and foundation of the house (Scenarios B and C) or commercial building (Scenario A) on the site reduce external exposure by $30 \%$; the indoor dust level is $40 \%$ of the outdoor dust level (Yu et al. 1993a).

- The outdoor airborne dust loading is $0.1 \mathrm{mg} / \mathrm{m}^{3}$. 
- The depth of the house or building foundation is $1 \mathrm{~m}$ below ground surface, with an effective radon diffusion coefficient of $2 \times 10^{-8} \mathrm{~m}^{2} / \mathrm{s}$ (Yu et al. 1993a).

- The size of the decontaminated area is sufficiently large that $10 \%$ and $50 \%$ of the plant food diet consumed by the resident and subsistence farmer for Scenarios B and C, respectively, is grown in a garden in the decontaminated area (Yu et al. 1993a). The industrial worker does not consume these plant foods.

- The size of the decontaminated area is sufficiently large to produce $50 \%$ of the forage used to feed livestock for meat and milk consumed by the subsistence farmer in Scenario C (Yu et al. 1993a). The industrial worker and the resident in Scenarios A and B do not consume these animal products.

- Half of the fish and other aquatic food consumed by the subsistence farmer in Scenario C is obtained from an on-site pond (Yu et al. 1993a).

- The current supply of water for the industrial building is from uncontaminated municipal sources, and this supply is assumed to be used under Scenarios A and B. However, for the plausible but unlikely scenario (Scenario C), the source of water for drinking, household uses, livestock watering, and irrigation is assumed to be an on-site well.

- The soil at the site is sand and gravel (Spieker 1965). Because of the lack of site-specific data, typical values for sandy soils tabulated in Yu et al. (1993a) are used for the density, total and effective porosities, soil " $\mathrm{b}$ " parameter, and hydraulic conductivity in the contaminated, unsaturated, and saturated zones.

- The uranium distribution coefficient was measured at $100 \mathrm{~cm}^{3} / \mathrm{g}$ for surface soil (Orlandini 1994); this value is used for all uranium isotopes in the contaminated, unsaturated, and saturated zones. The distribution coefficients of the radioactive progeny are those for sandy soils tabulated in Yu et al. (1993b).

- No wells have been dug at the site. The water table in the area ranges from as close as $2 \mathrm{~m}$ to more than $10 \mathrm{~m}$ below the soil surface (Sheets 1994; Spieker 1965); a distance of $3.8 \mathrm{~m}$ to the water table is assumed on the basis of the average water table in area wells.

- After remedial action, no cover material is placed over the decontaminated area. 
- No erosion of the contaminated material occurs.

- The thickness of the contaminated zone is based on conservative average values from ORNL measurements (Murray et al. 1993). The area of the former Associate Aircraft site $\left(10,000 \mathrm{~m}^{2}\right)$ is assumed to be homogeneously contaminated to an average depth of $0.3 \mathrm{~m}$. Of this area, approximately $3,700 \mathrm{~m}^{2}$ is now occupied by the building. 


\section{DOSE/SOURCE CONCENTRATION RATIOS}

To develop residual radioactivity guidelines for soil at the former Associate Aircraft site, the RESRAD computer code, version 5.41 (Yu et al. 1993a), was used to calculate the dose/source concentration ratio $D S R_{i p}(t)$ for uranium isotope $i$ and pathway $p$ at time $t$ after remedial action. The time frame considered for this analysis was 1,000 years. Radioactive decay and ingrowth were considered in deriving the dose/source concentration ratios. The various parameters used in the RESRAD code for this analysis are listed in the Appendix. The calculated maximum dose/source concentration ratios for all pathways are presented in Tables 2, 3, and 4 for Scenarios A, B, and C, respectively. For all three scenarios, the maximum dose/source concentration ratios would occur at time zero (immediately after remedial action). The dose from natural uranium in soil in Scenarios A and B is contributed primarily by external exposure and inhalation of dust. In Scenario C, the dose from natural uranium is contributed almost equally by the external exposure, dust inhalation, and plant ingestion pathways. that is,

The summation of $D S R_{i p}(t)$ for all pathways $p$ is the $D S R_{i}(t)$ for the ith isotope;

$$
D S R_{i}(t)=\sum_{p} D S R_{i p}(t) .
$$

The total dose/source concentration ratio for total uranium can be calculated as

$$
D S R(t)=\sum_{i} W_{i} D S R_{i}(t),
$$

where $W_{i}$ is the existing activity concentration fraction in soil at the site for uranium-234, uranium-235, and uranium-238.

For this analysis, $W_{i}$ is assumed to represent the natural activity concentration ratios of $1 / 2.046,1 / 2.046$, and $0.046 / 2.046$ for uranium-238, uranium-234, and uranium-235, respectively. The total dose/source concentration ratios for single radionuclides and total uranium are provided in Table 5. These ratios were used to determine the allowable residual radioactivity for uranium in soil at the former Associate Aircraft site.

Uncertainty in the derivation of dose/source concentration ratios arises from the distribution of possible input parameter values, as well as uncertainty in the conceptual model used to represent the site. Depending on the scenario, different parameters may affect the results in each case. For Scenarios A and B, the external exposure and inhalation pathways contribute almost equally to most of the dose. Therefore, uncertainty in parameters affecting these pathways, such as the thickness of the contaminated zone and mass loading of dust in the air, will affect the results more than parameters affecting other 
TABLE 2 Maximum Dose/Source Concentration Ratios for Scenario A (industrial worker: municipal water supply) at the Former Associate Aircraft Site

\begin{tabular}{|c|c|c|c|}
\hline \multirow[b]{2}{*}{ Pathway } & \multicolumn{3}{|c|}{$\begin{array}{l}\text { Maximum Dose/Source Concentration Ratio } \\
\text { (mrem } / \mathrm{yr}) /(\mathrm{pCi} / \mathrm{g})\end{array}$} \\
\hline & Uranium-234 & Uranium-235 & Uranium-238 \\
\hline External exposure & $2.7 \times 10^{-4}$ & $1.8 \times 10^{-1}$ & $2.4 \times 10^{-2}$ \\
\hline Inhalation & $1.3 \times 10^{-2}$ & $1.2 \times 10^{-2}$ & $1.2 \times 10^{-2}$ \\
\hline Radon & 0 & 0 & 0 \\
\hline Ingestion of soil & $2.5 \times 10^{-3}$ & $2.4 \times 10^{-3}$ & $2.4 \times 10^{-3}$ \\
\hline
\end{tabular}

a Maximum dose/source concentration ratios would occur at time zero (immediately following remedial action); all values are reported to two significant figures.

TABLE 3 Maximum Dose/Source Concentration Ratios for Scenario B (resident: municipal water supply) at the Former Associate Aircraft Site

\begin{tabular}{llll}
\hline & \multicolumn{3}{c}{ Maximum Dose/Source Concentration Ratio } \\
& \multicolumn{3}{c}{$\begin{array}{c}\text { a } \\
\text { Pathrem/yr)/(pCi/g) }\end{array}$} \\
\cline { 2 - 4 } \multicolumn{1}{c}{ Pathway } & Uranium-234 & Uranium-235 & Uranium-238 \\
\hline External exposure & $8.5 \times 10^{-4}$ & $5.5 \times 10^{-1}$ & $7.7 \times 10^{-2}$ \\
Inhalation & $4.8 \times 10^{-2}$ & $4.4 \times 10^{-2}$ & $4.4 \times 10^{-2}$ \\
Radon & 0 & 0 & 0 \\
Ingestion of plant foods & $3.8 \times 10^{-3}$ & $3.7 \times 10^{-3}$ & $3.7 \times 10^{-3}$ \\
Ingestion of soil & $7.1 \times 10^{-3}$ & $6.8 \times 10^{-3}$ & $6.8 \times 10^{-3}$ \\
\hline
\end{tabular}

a Maximum dose/source concentration ratios would occur at time zero (immediately following remedial action); all values are reported to two significant figures. 
TABLE 4 Maximum Dose/Source Concentration Ratios for Scenario C (subsistence farmer: on-site well water) at the Former Associate Aircraft Site

\begin{tabular}{llll}
\hline & \multicolumn{3}{c}{ Maximum $\begin{array}{c}\text { Dose/Source Concentration Ratio } \\
\text { (mrem/yr)/(pCi/g) }\end{array}$} \\
\cline { 2 - 4 } \multicolumn{1}{c}{ Pathway } & Uranium-234 & Uranium-235 & Uranium-238 \\
\hline External exposure & $8.5 \times 10^{-4}$ & $5.5 \times 10^{-1}$ & $7.7 \times 10^{-2}$ \\
Inhalation & $4.8 \times 10^{-2}$ & $4.4 \times 10^{-2}$ & $4.4 \times 10^{-2}$ \\
Radon & 0 & 0 & 0 \\
Ingestion of plant foods & $1.9 \times 10^{-2}$ & $1.8 \times 10^{-2}$ & $1.8 \times 10^{-2}$ \\
Ingestion of meat & $1.6 \times 10^{-3}$ & $1.5 \times 10^{-3}$ & $1.5 \times 10^{-3}$ \\
Ingestion of milk & $3.9 \times 10^{-3}$ & $3.8 \times 10^{-3}$ & $3.8 \times 10^{-3}$ \\
Ingestion of fish & 0 & 0 & 0 \\
Ingestion of soil & $7.1 \times 10^{-3}$ & $6.8 \times 10^{-3}$ & $6.8 \times 10^{-3}$ \\
Ingestion of water & 0 & 0 & 0 \\
\hline
\end{tabular}

a Maximum dose/source concentration ratios would occur at time zero (immediately following remedial action); all values are reported to two significant figures.

TABLE 5 Total Dose/Source Concentration Ratios for Uranium at the Former Associate Aircraft Site

\begin{tabular}{|c|c|c|c|}
\hline \multirow[b]{2}{*}{ Radionuclide } & \multicolumn{3}{|c|}{$\begin{array}{l}\text { Maximum Dose/Source Concentration Ratio } \\
(\mathrm{mrem} / \mathrm{yr}) /(\mathrm{pCi} / \mathrm{g})\end{array}$} \\
\hline & Scenario $\mathrm{A}^{\mathrm{b}}$ & Scenario $B^{c}$ & Scenario $C^{d}$ \\
\hline Uranium-234 & $1.6 \times 10^{-2}$ & $5.9 \times 10^{-2}$ & $8.0 \times 10^{-2}$ \\
\hline Uranium-235 & $1.9 \times 10^{-1}$ & $6.1 \times 10^{-1}$ & $6.3 \times 10^{-1}$ \\
\hline Uranium-238 & $3.9 \times 10^{-2}$ & $1.3 \times 10^{-1}$ & $1.5 \times 10^{-1}$ \\
\hline Total uranium & $3.1 \times 10^{-2}$ & $1.1 \times 10^{-1}$ & $1.3 \times 10^{-1}$ \\
\hline
\end{tabular}

a All values are reported to two significant figures.

b Industrial worker (current-use scenario): no consumption of water or food obtained on the site.

c Resident: water used for drinking, household purposes, and irrigation is assumed to be from uncontaminated municipal sources (likely future-use scenario).

d Subsistence farmer: water used for drinking, household purposes, livestock watering, and irrigation is assumed to be from an on-site well (unlikely future-use scenario). 
pathways. In addition, doses will depend strongly on the choice of occupancy factors selected for these two scenarios. In addition to the external gamma exposure and dust inhalation pathways, the plant ingestion pathway also contributes significantly to the dose calculated for Scenario C. Therefore, the guidelines for Scenario C will also be sensitive to parameters that affect this pathway, such as root uptake factors and plant ingestion rates.

Because the maximum dose occurs at time zero in all three scenarios, uncertainties in parameters that affect the leaching of radionuclides from the contaminated zone and their transport through unsaturated and saturated strata do not affect the results. It should be noted that the breakthrough time (the time it takes the uranium to reach the water table) is estimated to occur 600 years after remediation; however, the dose contribution from waterdependent pathways in Scenario $\mathrm{C}$ is smaller than the contribution of the water-independent pathways at the time of peak dose. Changing the depth to the water table only affects the breakthrough time, it does not significantly affect the magnitude of the dose contributed by water-dependent pathways.

The RESRAD default values were used in the calculations if no site-specific data were available. These defaults are based on national average or reasonable maximum values. In addition, the contaminated zone thickness of $0.3 \mathrm{~m}$ that was selected to derive the dose/source concentration ratios is based on the assumption that the soil is uniformly contaminated to that depth. In reality, the contamination occurs mostly in the top $15 \mathrm{~cm}$ of soil and is not dispersed uniformly throughout the site. For Scenario A, the thick concrete slab currently under the building would provide a significant amount of attenuation to external gamma radiation. In Scenarios B and C, it is likely that large amounts of potentially contaminated soil and demolition debris would be removed in preparing the site for residential or farming use. Therefore, the calculated dose/source ratios are conservative. 


\section{RESIDUAL RADIOACTIVE MATERIAL GUIDELINES}

The residual radioactive material guideline is the concentration of residual radioactive material that can remain in the soil in a decontaminated area and still permit use of the area without radiological restrictions. Given a dose limit, DL, for an individual, the residual radioactive material guideline $G$ for uranium at the former Associate Aircraft site can be calculated as

$$
G=D L / D S R,
$$

where $D S R$ is the total dose/source concentration ratio listed in Table 5. The dose limit, DL, used to derive the residual radioactive material guideline is $30 \mathrm{mrem} / \mathrm{yr}$ for the current-use and likely future-use scenarios and $100 \mathrm{mrem} / \mathrm{yr}$ for all other plausible future-use scenarios ( $\mathrm{Yu}$ et al. 1993a). The calculated residual radioactive material guidelines for single radionuclides (uranium-234, uranium-235, and uranium-238) and total uranium are presented in Table 6.

For the calculations of the guidelines for total uranium, it was assumed that the activity concentration ratio of uranium-238, uranium-234, and uranium-235 is 1:1:0.046. The

TABLE 6 Residual Radioactive Material Guidelines for the Former Associate Aircraft Site

\begin{tabular}{lccc}
\hline & \multicolumn{3}{c}{ Guideline $^{\mathrm{a}}(\mathrm{pCi} / \mathrm{g})$} \\
\cline { 2 - 4 } Radionuclide & Scenario $^{\mathrm{b}}$ & Scenario $^{\mathrm{c}}$ & Scenario C $^{\mathrm{d}}$ \\
\hline & & & \\
Uranium-234 & 1,900 & 500 & 1,200 \\
Uranium-235 & 160 & 50 & 160 \\
Uranium-238 & 780 & 230 & 660 \\
Total uranium & 970 & 280 & 790 \\
\hline
\end{tabular}

a All values are reported to two significant figures.

b Industrial worker: no consumption of water or food obtained on the site (current-use scenario, dose constraint = $30 \mathrm{mrem} / \mathrm{yr}$ ).

c Resident: water used for drinking, household purposes, and irrigation is assumed to be from uncontaminated municipal sources (likely future-use scenario, dose constraint = $30 \mathrm{mrem} / \mathrm{yr}$ ).

d Subsistence farmer: water used for drinking, household purposes, livestock watering, and irrigation is assumed to be from an on-site well (unlikely but plausible future-use scenario, dose limit $=100 \mathrm{mrem} / \mathrm{yr}$ ). 
derived guidelines for total uranium are 970,280 , and $790 \mathrm{pCi} / \mathrm{g}$ for Scenarios A, B, and C, respectively. If uranium-238 is measured as the indicator radionuclide, the uranium-238 limits for total uranium can be calculated by dividing the total uranium guidelines by 2.046 . The resulting uranium-238 limits are 470,140 , and $390 \mathrm{pCi} / \mathrm{g}$ for Scenarios A, B, and C, respectively.

The law of sum of fractions applies when the derived radionuclide guidelines for decontamination of a site are implemented. That is, the summation of the radionuclide concentrations $S_{i}$ remaining on-site (averaged over an area of $100 \mathrm{~m}^{2}$ and a depth of $15 \mathrm{~cm}$ ) divided by their guidelines $G_{i}$ should not be greater than unity; that is,

$$
\sum_{i} S_{i} / G_{i} \leq 1 .
$$

The derived guidelines listed in Table 6 are for a large, homogeneously contaminated area. For a small, isolated area of contamination (a hot spot), the allowable concentration that can remain on-site may be higher than the homogeneous guideline, depending on the size of the contaminated area and in accordance with the ranges given in Table 7.

TABLE 7 Ranges for Hot-Spot Multiplication Factors

\begin{tabular}{cc}
\hline $\begin{array}{c}\text { Area } \\
\text { Range }\left(\mathrm{m}^{2}\right)\end{array}$ & $\begin{array}{c}\text { Factor } \\
\text { (multiple of } \\
\text { authorized limit) }\end{array}$ \\
\hline$<1$ & $10^{\mathrm{a}}$ \\
$1-<3$ & 6 \\
$3-<10$ & 3 \\
$10-25$ & 2 \\
\hline
\end{tabular}

a Areas less than $1 \mathrm{~m}^{2}$ are to be averaged over a $1-\mathrm{m}^{2}$ area, and that average shall not exceed 10 times the authorized limit.

Source: Yu et al. (1993a). 


\section{REFERENCES}

Murray, M.E., et al., 1993, Results of the Radiological Survey at the Former Associate Aircraft Tool and Manufacturing Company Site, Fairfield, Ohio (FOH001), ORNL/RASA-93/2, Health and Safety Research Division, Oak Ridge National Laboratory, Oak Ridge, Tenn., March.

Orlandini, K.A., 1994, personal communication from Orlandini (Environmental Research Division) to C. Yu (Environmental Assessment Division), Argonne National Laboratory, Argonne, Ill., Dec. 19.

Sheets, R.A., 1994, letter from Sheets (Ohio District Water Resources Division, U.S. Department of the Interior, Columbus, Ohio) to E.R. Faillace (Environmental Assessment Division, Argonne National Laboratory, Argonne, Ill.), Dec. 8.

Spieker, A.M., 1965, Hydrogeologic Aspects of an Analog Model Study of the Fairfield-New Baltimore Area, Ohio, doctoral thesis, Stanford University, Stanford, Calif.

U.S. Department of Energy, 1990, Radiation Protection of the Public and Environment, DOE Order 5400.5, Washington, D.C., Feb.

Yu, C., et al., 1993a, Manual for Implementing Residual Radioactive Material Guidelines Using RESRAD, Version 5.0, ANL/EAD/LD-2, Argonne National Laboratory, Argonne, Ill., Sept.

Yu, C., et al., 1993b, Data Collection Handbook to Support Modeling the Impacts of Radioactive Material in Soil, ANL/EAIS-8, Argonne National Laboratory, Argonne, Ill., April. 


\section{APPENDLX:}

\section{SCENARIOS AND PARAMETERS USED FOR THE ANALYSIS OF THE FORMER ASSOCLATE AIRCRAFT SITE}

The following exposure scenarios were analyzed for the former Associate Aircraft site in Fairfield, Ohio:

- Scenario A: Industrial Use of the Site - Municipal Water Supply. A hypothetical person is assumed to work in the area of the site.

- Scenario B: Residential Use of the Site - Municipal Water Supply. A hypothetical resident is assumed to live in the decontaminated area and to use an uncontaminated municipal water supply for drinking, household purposes, and irrigation. The resident is assumed to ingest plant foods grown on-site; however, no livestock are raised on-site for the production of meat and milk, and no pond is present on-site to provide fish and other aquatic food.

- Scenario C: Subsistence Farming Use of the Site - On-Site Well Water. A hypothetical subsistence farmer is assumed to live in the decontaminated area and to use water from an on-site well for drinking, household purposes, livestock watering, and irrigation. The resident is assumed to ingest plant foods grown in the garden and meat and milk from livestock fed with forage grown on-site. The resident is assumed to catch and consume fish and other aquatic organisms from an on-site pond.

The parametric values used in the RESRAD code for the analysis of the former Associate Aircraft site are listed in Table A.1. These values are reported at up to three significant figures. Some parameters are specific to the former Associate Aircraft site; others are generic. 
TABLE A.1 Parameters Used in the RESRAD Computer Code for the Analysis of the Former Associate Aircraft Site

\begin{tabular}{|c|c|c|c|c|}
\hline \multirow[b]{2}{*}{ Parameter } & \multirow[b]{2}{*}{ Unit } & \multicolumn{3}{|c|}{ Value } \\
\hline & & Scenario A & Scenario B & Scenario C \\
\hline Area of contaminated zone $\mathrm{e}^{\mathrm{a}}$ & $\mathrm{m}^{2}$ & 10,000 & 10,000 & 10,000 \\
\hline Thickness of contaminated zone & $\mathrm{m}$ & 0.3 & 0.3 & 0.3 \\
\hline Length parallel to aquifer flowa & $\mathrm{m}$ & Not used & Not used & 100 \\
\hline Basic radiation dose limit ${ }^{a, b}$ & $\mathrm{mrem} / \mathrm{yr}$ & 30 & 30 & 100 \\
\hline Cover depth & m & 0 & 0 & 0 \\
\hline \multicolumn{5}{|l|}{ Contaminated zone } \\
\hline Density ${ }^{b}$ & $\mathrm{~g} / \mathrm{cm}^{3}$ & 1.5 & 1.5 & 1.5 \\
\hline Erosion rate ${ }^{a}$ & $\mathrm{~m} / \mathrm{yr}$ & 0 & 0 & 0 \\
\hline Total porosity & $-\mathbf{c}$ & 0.4 & 0.4 & 0.4 \\
\hline Effective porosity ${ }^{a}$ & - $^{c}$ & 0.3 & 0.3 & 0.3 \\
\hline Hydraulic conductivity ${ }^{2}$ & $\mathrm{~m} / \mathrm{yr}$ & 5,000 & 5,000 & 5,000 \\
\hline Soil-specific b parameter ${ }^{a}$ & $-c$ & 4.05 & 4.05 & 4.05 \\
\hline Evapotranspiration coefficient ${ }^{b}$ & $-^{c}$ & 0.5 & 0.5 & 0.5 \\
\hline Precipitation & $\mathrm{m} / \mathrm{yr}$ & 0.99 & 0.99 & 0.99 \\
\hline Irrigation $^{\mathrm{b}}$ & $\mathrm{m} / \mathrm{yr}$ & 0.2 & 0.2 & 0.2 \\
\hline Irrigation mode ${ }^{b}$ & $-c$ & Overhead & Overhead & Overhead \\
\hline Runoff coefficient $t^{b}$ & $-\mathbf{c}$ & 0.2 & 0.2 & 0.2 \\
\hline Watershed area for nearby pond $d^{a, b}$ & $\mathrm{~m}^{2}$ & Not used & Not used & $1,000,000$ \\
\hline Accuracy for water/soil computations ${ }^{a, b}$ & - & Not used & Not used & 0.001 \\
\hline \multicolumn{5}{|l|}{ Saturated zone } \\
\hline Density ${ }^{a, b}$ & $\mathrm{~g} / \mathrm{cm}^{3}$ & Not used & Not used & 1.5 \\
\hline Total porositya & $-c$ & Not used & Not used & 0.4 \\
\hline Effective porosity ${ }^{a}$ & $-\mathbf{c}$ & Not used & Not used & 0.3 \\
\hline Hydraulic conductivity & $\mathrm{m} / \mathrm{yr}$ & Not used & Not used & 5,000 \\
\hline Hydraulic gradien $\mathrm{t}^{\mathrm{a}, \mathrm{b}}$ & $-\mathrm{c}$ & Not used & Not used & 0.02 \\
\hline Water table drop rate & $\mathrm{m} / \mathrm{yr}$ & Not used & Not used & 0 \\
\hline Well pump intake depth (below water table) ) $^{\mathrm{a}, \mathrm{b}}$ & m & Not used & Not used & 10 \\
\hline $\begin{array}{l}\text { Model: nondispersion (ND) or mass } \\
\text { balance }(\mathrm{MB})^{\mathrm{a}, \mathrm{b}}\end{array}$ & $-\mathrm{c}$ & Not used & Not used & $\mathrm{ND}$ \\
\hline Well pumping rate ${ }^{a, b}$ & $\mathrm{~m}^{3} / \mathrm{yr}$ & Not used & Not used & 250 \\
\hline Number of unsaturated zone strata & c & Not used & Not used & 1 \\
\hline \multicolumn{5}{|l|}{ Unsaturated zone } \\
\hline Thickness & m & Not used & Not used & 3.5 \\
\hline Soil density ${ }^{a, b}$ & $\mathrm{~g} / \mathrm{cm}^{3}$ & Not used & Not used & 1.5 \\
\hline Total porosity ${ }^{a}$ & c c & Not used & Not used & 0.4 \\
\hline Effective porosity ${ }^{a}$ & $-\mathbf{c}$ & Not used & Not used & 0.3 \\
\hline Soil-specific b parameter ${ }^{a}$ & $-\mathbf{c}$ & Not used & Not used & 4.05 \\
\hline Hydraulic conductivity ${ }^{\mathrm{a}, \mathrm{b}}$ & $\mathrm{m} / \mathrm{yr}$ & Not used & Not used & 5,000 \\
\hline \multicolumn{5}{|l|}{ Distribution coefficient ${ }^{\mathrm{a}}$ (all zones) } \\
\hline Uranium-234 & & 100 & 100 & 100 \\
\hline Uranium-235 & & 100 & 100 & 100 \\
\hline Uranium-238 & & 100 & 100 & 100 \\
\hline Actinium-227 & & 450 & 450 & 450 \\
\hline Protactinium-231 & & 550 & 550 & 550 \\
\hline Lead-210 & & 270 & 270 & 270 \\
\hline Radium-226 & & 500 & 500 & 500 \\
\hline Thorium-230 & & 3,200 & 3,200 & 3,200 \\
\hline Inhalation rate ${ }^{b}$ & $\mathrm{~m}^{3} / \mathrm{yr}$ & 8,400 & 8,400 & 8,400 \\
\hline Mass loading for inhalation ${ }^{2}$ & $\mathrm{~g} / \mathrm{m}^{3}$ & 0.0001 & 0.0001 & 0.0001 \\
\hline Shielding factor, inhalation ${ }^{b}$ & $-c$ & 0.4 & 0.4 & 0.4 \\
\hline Shielding factor, external gamma ${ }^{b}$ & $\sim^{c}$ & 0.7 & 0.7 & 0.7 \\
\hline Fraction of time indoors $\mathrm{a}^{\mathrm{a}, \mathrm{b}}$ & $-c$ & 0.23 & 0.5 & 0.5 \\
\hline Fraction of time outdoors ${ }^{a, b}$ & $一^{c}$ & 0.03 & 0.25 & 0.25 \\
\hline
\end{tabular}




\begin{tabular}{|c|c|c|c|c|}
\hline \multirow[b]{2}{*}{ Parameter } & \multirow[b]{2}{*}{ Unit } & \multicolumn{3}{|c|}{ Value } \\
\hline & & Scenario A & Scenario B & Scenario C \\
\hline Shape factor, external gamma ${ }^{b}$ & $-c$ & 1 & 1 & 1 \\
\hline Dilution length for airborne dust, inhalation ${ }^{b}$ & m & 3 & 3 & 3 \\
\hline \multicolumn{5}{|l|}{ Food consumption } \\
\hline Fruits, vegetables, and grain ${ }^{a, b}$ & $\mathrm{~kg} / \mathrm{yr}$ & Not used & 160 & 160 \\
\hline Leafy vegetables ${ }^{a, b}$ & $\mathrm{~kg} / \mathrm{yr}$ & Not used & 14 & 14 \\
\hline Milk $^{\mathrm{a}, \mathrm{b}}$ & $\mathrm{L} / \mathrm{yr}$ & Not used & Not used & 92 \\
\hline Meat and poultry ${ }^{a, b}$ & $\mathrm{~kg} / \mathrm{yr}$ & Not used & Not used & 63 \\
\hline Fish $^{a, b}$ & $\mathrm{~kg} / \mathrm{yr}$ & Not used & Not used & 5.4 \\
\hline Other aquatic food ${ }^{a, b}$ & $\mathrm{~kg} / \mathrm{yr}$ & Not used & Not used & 0.9 \\
\hline Soil ingestion ${ }^{\mathrm{b}}$ & $\mathrm{g} / \mathrm{yr}$ & 36.5 & 36.5 & 36.5 \\
\hline Drinking water intake $e^{a, b}$ & $\mathrm{~L} / \mathrm{yr}$ & Not used & Not used & 510 \\
\hline \multicolumn{5}{|l|}{ Contaminated fraction of food and water } \\
\hline Drinking water ${ }^{a, b}$ & & Not used & Not used & 1 \\
\hline Household water ${ }^{a, b}$ & & 0 & 0 & 1 \\
\hline Livestock water ${ }^{a, b}$ & & Not used & Not used & 1 \\
\hline Irrigation water ${ }^{a, b}$ & & Not used & 0 & 1 \\
\hline Aquatic food $d^{a, b}$ & & Not used & Not used & 0.5 \\
\hline Plant food ${ }^{a}$ & & Not used & 0.1 & $0.5^{\mathrm{d}}$ \\
\hline Meat ${ }^{\mathrm{a}}$ & & Not used & Not used & $0.5^{\mathrm{d}}$ \\
\hline Milk $^{\mathrm{a}}$ & & Not used & Not used & $0.5^{\mathrm{d}}$ \\
\hline Livestock fodder intake for meat ${ }^{a, b}$ & $\mathrm{~kg} / \mathrm{d}$ & Not used & Not used & 68 \\
\hline Livestock fodder intake for milk ${ }^{\mathrm{a}, \mathrm{b}}$ & $\mathrm{kg} / \mathrm{d}$ & Not used & Not used & 55 \\
\hline Livestock water intake for meat ${ }^{\mathrm{a}, \mathrm{b}}$ & $L / d$ & Not used & Not used & 50 \\
\hline Livestock water intake for milk ${ }^{a, b}$ & $\mathrm{~L} / \mathrm{d}$ & Not used & Not used & 160 \\
\hline Livestock soil intake $\mathrm{e}^{\mathrm{a}, \mathrm{b}}$ & $\mathrm{kg} / \mathrm{d}$ & Not used & Not used & 0.5 \\
\hline Mass loading for foliar deposition ${ }^{a, b}$ & $\mathrm{~g} / \mathrm{m}^{3}$ & Not used & 0.0001 & 0.0001 \\
\hline Depth of soil mixing layer & $\mathbf{m}$ & 0.15 & 0.15 & 0.15 \\
\hline Depth of roots ${ }^{a, b}$ & $\mathrm{~m}$ & Not used & 0.9 & 0.9 \\
\hline $\begin{array}{l}\text { Groundwater fractional usage (balance } \\
\text { from surface water) }\end{array}$ & $-c$ & & & \\
\hline Drinking water ${ }^{a, b}$ & & Not used & Not used & 1 \\
\hline Household water ${ }^{a, b}$ & & Not used & Not used & 1 \\
\hline Livestock water ${ }^{a, b}$ & & Not used & Not used & 1 \\
\hline \multirow{2}{*}{\multicolumn{5}{|c|}{$\begin{array}{l}\text { Irrigation }{ }^{\mathrm{a}, \mathrm{b}} \\
\text { Storage time of contaminated foodstuffs }\end{array}$}} \\
\hline & & & & \\
\hline Fruits, non-leafy vegetables, and grain ${ }^{a, b}$ & & Not used & 14 & 14 \\
\hline Leafy vegetables ${ }^{\mathrm{a}, \mathrm{b}}$ & & Not used & 1 & 1 \\
\hline Fish $^{a, b}$ & & Not used & Not used & 7 \\
\hline Crustacea and mollusks ${ }^{a, b}$ & & Not used & Not used & 7 \\
\hline Milk $^{\mathrm{a}, \mathrm{b}}$ & & Not used & Not used & $\dot{1}$ \\
\hline Meat and poultry ${ }^{\mathrm{a}, \mathrm{b}}$ & & Not used & Not used & 20 \\
\hline Well water ${ }^{a, b}$ & & Not used & Not used & 1 \\
\hline Livestock fodder ${ }^{a, b}$ & & Not used & Not used & 45 \\
\hline $\begin{array}{l}\text { Total porosity of the house or building } \\
\text { foundation } \mathrm{b}\end{array}$ & $-^{c}$ & 0.1 & 0.1 & 0.1 \\
\hline Volumetric water content of the foundation ${ }^{b}$ & $-^{c}$ & 0.03 & 0.03 & 0.03 \\
\hline \multicolumn{5}{|l|}{ Diffusion coefficient for radon gas } \\
\hline In foundation material ${ }^{b}$ & & $3.0 \times 10^{-7}$ & $3.0 \times 10^{-7}$ & $3.0 \times 10^{-7}$ \\
\hline In contaminated zone soil ${ }^{\mathrm{b}}$ & & $2.0 \times 10^{-6}$ & $2.0 \times 10^{-6}$ & $2.0 \times 10^{-6}$ \\
\hline Emanating power of radon-222 $2^{b}$ & $-^{c}$ & 0.25 & 0.25 & 0.25 \\
\hline Radon vertical dimension of mixing ${ }^{b}$ & $\mathbf{m}$ & 2 & 2 & 2 \\
\hline Average annual wind speed ${ }^{\mathrm{b}}$ & $\mathrm{m} / \mathrm{s}$ & 2 & 2 & 2 \\
\hline Average building air exchange rate ${ }^{b}$ & $1 / \mathrm{h}$ & 0.5 & 0.5 & 0.5 \\
\hline Height of building (room) ${ }^{b}$ & $\mathbf{m}$ & 2.5 & 2.5 & 2.5 \\
\hline
\end{tabular}


TABLE A.1 (Cont.)

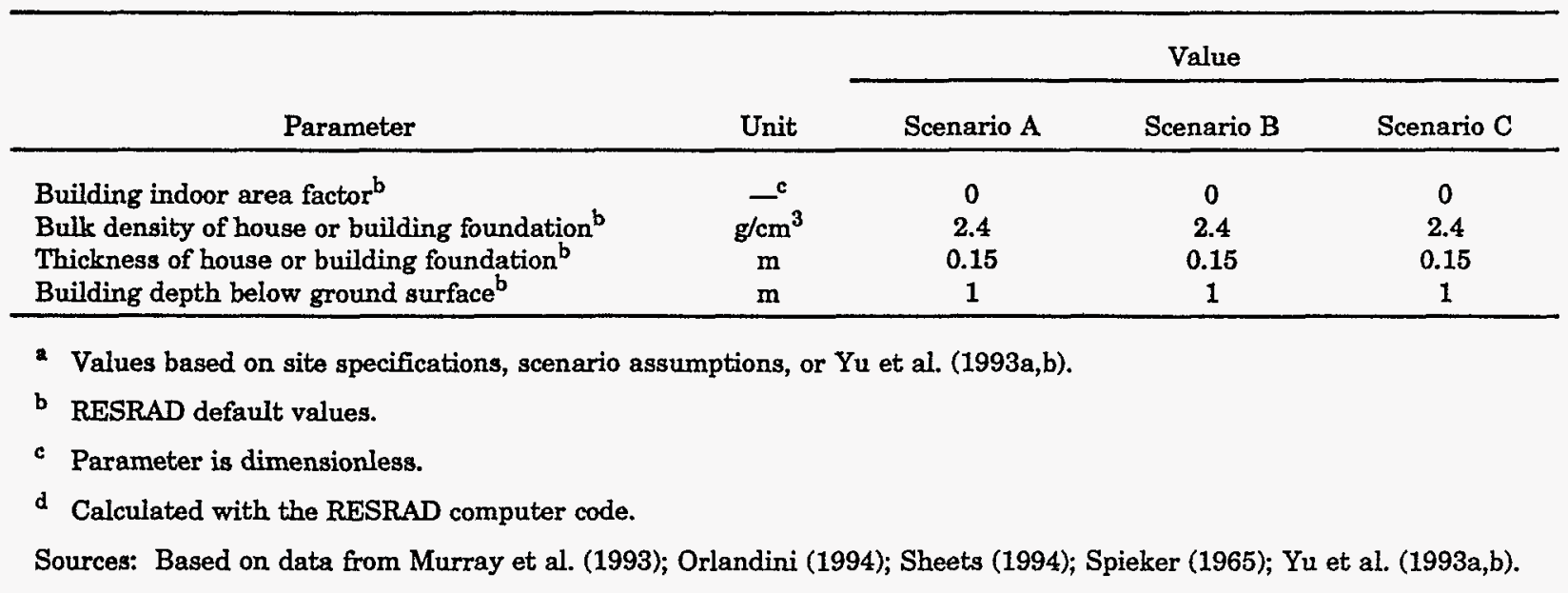

\section{REFERENCES}

Murray, M.E., et al., 1993, Results of the Radiological Survey at the Former Associate Aircraft Tool and Manufacturing Company Site, Fairfield, Ohio (FOHO01), ORNL/RASA-93/2, Health and Safety Research Division, Oak Ridge National Laboratory, Oak Ridge, Tenn., March.

Orlandini, K.A., 1994, personal communication from Orlandini (Environmental Research Division) to C. Yu (Environmental Assessment Division), Argonne National Laboratory, Argonne, Ill., Dec. 19.

Sheets, R.A., 1994, letter from Sheets (Ohio District Water Resources Division, U.S. Department of the Interior, Columbus, Ohio) to E.R. Faillace (Environmental Assessment Division, Argonne National Laboratory, Argonne, Ill.), Dec. 8.

Spieker, A.M., 1965, Hydrogeologic Aspects of an Analog Model Study of the Fairfield-New Baltimore Area, Ohio, doctoral thesis, Stanford University, Stanford, Calif.

Yu, C., et al., 1993a, Manual for Implementing Residual Radioactive Material Guidelines Using RESRAD, Version 5.0, ANL/EAD/LD-2, Argonne National Laboratory, Argonne, Ill., Sept.

Yu, C., et al., 1993b, Data Collection Handbook to Support Modeling the Impacts of Radioactive Material in Soil, ANL/EAIS-8, Argonne National Laboratory, Argonne, III., April. 